\title{
STUDIES OF TONSILLITIS FROM THE ASPECT OF PROTEASE-ANTIPROTEASE
}

\section{ARTHUS TONSILLITIS OF RABBIT AND FIBRINOLYTIC ACTIVITY OF BLOOD}

TADAYOSHI KOSUGI, M.D.

Department of Physiology, Miyazaki Medical College, Miyazakı

(Director: H. Mihara, M.D.)

In order to clarify the relationship between inflammatory process and fibrinolytic system, Arthus-type hypersensitivity was experimentally designed in rabbit tonsil. At the beginning of this study, we discussed if Arthus tonsillitis of rabbit was useful or not as the model of human acute tonsillitis. Furthermore, macroscopic, histopathological findings were obtained and fibrinolytic activity of blood was estimated in parallel with the process of the Arthus tonsillitis.

These results obtained from this experiment were as follows:

1) In the first day after Arthus phenomenon was provoked at the tonsil of rabbit, the swelling and bleeding were macroscopically observed. In the 7 th day, however, these findings subsided.

2) The tonsil was divided into six portions, which were lacunal epithelium, interstitial portion of parenchyma, follicle, blood vessels, capsule and connective tissue surrounding the tonsil, and they were histopathologically observed. In the first day, the remarkable cell infiltrations and bleeding were observed at interstitial portion of parenchyma and connective tissue surrounding the tonsil.

3) As the parameters of fibrinolytic system in blood, the content of fibrinogen, content of plasminogen, inhibitor activity and whole plasmin (euglobulin + streptokinase) were estimated. In comparison with the control group, the increase of fibrinogen content, slight decrease of plasminogen content and remarkable decrease of whole plasmin were observed from first to third day.

4) To summarize these findings, in the first day after Arthus tonsillitis, strong inflammatory reactions were observed at the local site. In accordance with these local inflammatory reactions, fibrinolytic activity of blood increased. From these results, fibrinolytic activity of blood was correlated to the inflammatory process of Arthus tonsillitis, furthermore it may modify the clinical process of the tonsillitis.

A81-1531-52130

\section{Protease-antiprotease の観点よりみた扁桃炎の研究}

\section{第 3 報 家兔のアルサス型扁桃炎における血中線溶動態}

宮崎医科大学生理学第 II 講座（王任：美原 恒教授)

小杉垫誠

\section{第一節 アルサス型扁桃炎の病理組織学的検討}

\section{I. 緒䚻}

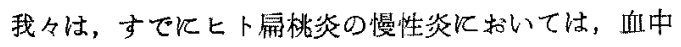

線溶活性の低下傾问 ${ }^{122}$, 急性炎ではその元進が琶められ

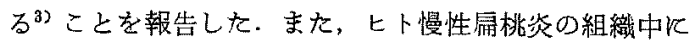
は，線溶系関与物質として urokinase inhibitor, pro-

$12-15$ 


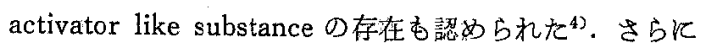
は，細川も述べているように， tissue plasminogen activator の存在も認められた ${ }^{53 日)}$. しかしながら，急性

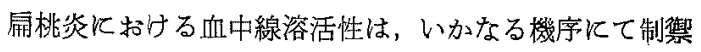
されているのか，また血中線溶活性の六進をひきおこす trigger substance は何であるのか, 未だ明らかとなっ ていない,一方, 扁桃局所の線溶系関与物質と血中線溶 活性の動的相関が，どの上うな形に拈いて存在するのか も未だ充分には解明されていない，以上述へた問題を解 明するため汇はまず急性扁桃炎モデルの作製が必要と なった，そこで, 家兔扁桃にアルサス現象を惹起し, 肉 眼的, 病理組織学的検討を行い, 急性惡桃炎モデルとし て有用であるかを，血中線溶動態との関連に括いて検討 したので報告する。

\section{II. 実験方法}

\section{○実験動物}

白色家鬼の雄を井いた。実験開始時の体重は500gr.$1 \mathrm{~kg}$ であった. 実験終了時の体重は $1 \mathrm{~kg}-2.5 \mathrm{~kg}$ であっ r.

\section{○感作方法}

抗原は Miles 製の Bovine Serum Albumin（以下 BSA と略す) を生理的食塩水（以下生食水之略す）飞 溶解したものを用いた. BSA $(4 \mathrm{mg} / \mathrm{ml})$ と Complete Freund Adjuvant (Difco 笠) の等量を混し，背部皮内 飞注射した。初回注射後 2 日招き飞 2 回 booster dose 投与を行い，随時採血し抗体価の測定を行った（図 1).

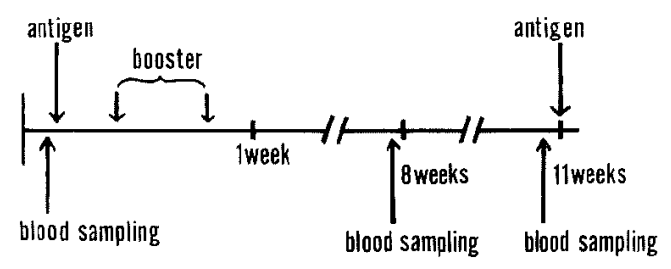

図 1 家鬼の感作方法

\section{○抗体価の測定方法}

緒方等の方法火準じて, 沈降反応による重層法にて測 定したり。抗体佂住血清の最高稀釈倍数に上って示した。 ○薏起注射の方法

感作家鬼の抗体価が $2^{4} \sim 2^{5}$ K達した洔点で意起注射

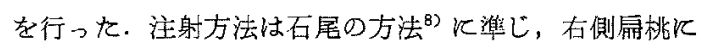
BSA $(4 \mathrm{mg} / \mathrm{m} l)$. $0.2-0.3 \mathrm{~m} l$ 注射した. 一方左側扁桃 飞は肉眼的, 組織学的に右側府桃と比較するために，牛
食水 $0.2-0.3 \mathrm{~m} l$ を注射した（家我番号 $13 \sim 26,30 \sim 32$ ). また家鬼番号27２9は，右側屚桃飞惹起注射を行い，左 側屚桃は無処置にて病理組織学的観察を行った. さらに 対照群として, 非感作家鬼の右側扁桃次 BSA (4mg/ $\mathrm{m} l$ ) $0.2-0.3 \mathrm{~m} l$, 左側扁桃牲食水 $0.2-0.3 \mathrm{~m} l$ を注 射した (家鬼番号 1 12).

\section{○肉眼的特よび病理組織学的観察}

㟟起注射施行後，3 時間，6時間，1日，2日，3日， 7 日K Nembutal 麻醉下K, 前頝部上り切開を加え, 舌 上共に両侧扁桃を一媿として摘出し, 肉眼的, 組織学的 観察を行った．対照群も同様に, 経時的, 経日的に観察 を行った．肉眼的には，屚桃実質部之周囲部の咽頭粘膜 の状態を観察した．すなわち，浮腫の認められるすの $(+)$ ，充血の認められるるの(十), 出血の認められる

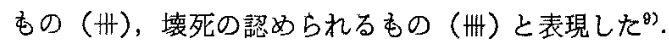
肉眼的観察終了後, 扁桃周囲部の一部を含めて硧桃を摘 出し，10\%フォルマリンにて固定し，型のごとく病理組 織標本を作製した. 染色梳 Haematoxylin-Eosin Kて行 った。病理組織標本での観察部位は，陰營粘莫上皮，実 質内間犋，洰胞，被膜，血管括よび実質外周国結合織の 6個の部分であった．それぞれの変化が軽度のあの(+) 中等度のもの (H), 強度のもの (H) と表現し, ごく 僅かな変化のものを（士）と表現した。

\section{III. 実験結果}

\section{○肉眼的所見}

アルサス反応惹起群に括いて，惹起注射施行後 3 日ま で, 生食水注射扁桃比比して明らか飞炎症性変化が强く 認められた，とくに，䓯起注射狏行後，1日，2 日最 あ強く出血性変化が認められた．この変化は，実質部分 より周囲部汇强い傾向が認められた。しかし，壊死性変 化は1例炕も認如られなかった。また，惹起注射施行後 7 日にては，殆んど炎症性変化が認められなくなってい た.これらの結果を一括して表、に示した。 反応惹起群

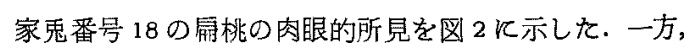
非感作家兔の対照群炕いて，BSA 注射の屚桃では,

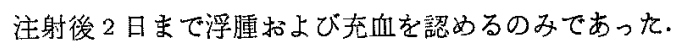
さらKこれらの変化性, 注射後比較的早期飞消失するの が認められた (表 2 ).

O病理組織学的所見

対照群（家兔番号“4,5）での:BSA 注射屚桃の組織像 は, 陰简粘膜上皮部の脱落, 細胞浸潤执よび実質内間質 の細胞浸潤を軽度認めるのみであった，また，実質外周 用結合織俚性柽度の出血を認めるのみであった。一方, 
表 1 感作家航の扁桃（肉眼的所見）

\begin{tabular}{|c|c|c|c|c|}
\hline 家鬼番号 焉 & 桃 & $\begin{array}{l}\text { 肉眼 } \\
\text { 実 質 }\end{array}$ & $\begin{array}{l}\text { 的 所見 } \\
\text { 周 国 部 }\end{array}$ & $\begin{array}{l}\text { 惹起後の } \\
\text { 経過 }\end{array}$ \\
\hline 13 & $\begin{array}{l}\text { 右 } \\
\text { 左 }\end{array}$ & + & + & 3時間 \\
\hline 14 & $\begin{array}{l}\text { 右 } \\
\text { 左 }\end{array}$ & + & \pm & 3時間 \\
\hline 15 & $\begin{array}{l}\text { 右 } \\
\text { 左 }\end{array}$ & H & H & 6時間 \\
\hline 16 & $\begin{array}{l}\text { 右 } \\
\text { 左 }\end{array}$ & \pm & $\overline{-}$ & 6時間 \\
\hline 17 & $\begin{array}{l}\text { 右 } \\
\text { 左 }\end{array}$ & \pm & +4 & 1日後 \\
\hline 18 & $\begin{array}{l}\text { 右 } \\
\text { 左 }\end{array}$ & 册 & $\begin{array}{l}\text { Ht } \\
+\end{array}$ & 1日後 \\
\hline 19 & $\begin{array}{l}\text { 右 } \\
\text { 左 }\end{array}$ & H & H & 1日後 \\
\hline 20 & $\begin{array}{l}\text { 右 } \\
\text { 左 }\end{array}$ & H & $\begin{array}{l}\text { Hit } \\
+\end{array}$ & 2日後 \\
\hline 21 & $\begin{array}{l}\text { 右 } \\
\text { 左 }\end{array}$ & \pm & $\begin{array}{l}+ \\
+\end{array}$ & 2日後 \\
\hline 22 & $\begin{array}{l}\text { 右 } \\
\text { 左 }\end{array}$ & H & H & 2日㣪 \\
\hline 23 & $\begin{array}{l}\text { 右 } \\
\text { 左 }\end{array}$ & H & H & 3日後 \\
\hline 24 & $\begin{array}{l}\text { 右 } \\
\text { 左 }\end{array}$ & $\overline{-}$ & \pm & 3日後 \\
\hline 25 & $\begin{array}{l}\text { 右 } \\
\text { 左 }\end{array}$ & - & - & 7日後 \\
\hline 26 & $\begin{array}{l}\text { 右 } \\
\text { 左 }\end{array}$ & - & - & 2日後 \\
\hline
\end{tabular}

右: BSA 注射

左: 生食水注射

反応薏起群では，惹起注射施行後 3 時間（家兔番号 13） に陰简粘膜上皮部の上皮脱落，実質内間質叔よび沪胞の 細胞浸潤を軽度飞認めた。また，扁桃周团部の結合織に は軽度の出血を認めた。しかし, 惹起注射施行後 1 日か ら3日では，これらの変化は顕著となり，とくに細胞浸 潤江加党て，陰窝粘膜上皮部，実質内間質の出血，血管 の充血像も出現してきた（家兔番号18, 19, 20, 23,30,32） 一方, 実質内間質, 洰胞部の壊死, および血管の血栓形 成は一例も認められなかった。実質外周围結合織徨加 な壊死を認めたものはごく少数例であった(家鬼番号 27 ， 28,29 ). 家鬼番号 18 のSA 注射甪桃（右屜桃）の病 理組織像では, 陰窝粘膜上皮の脱落, 細胞浸潤が著明飞 認められ，細胞の腫脹膨化も出現している（図3)。ま
表 2 非感作家兔の屚桃（肉眼的所見）

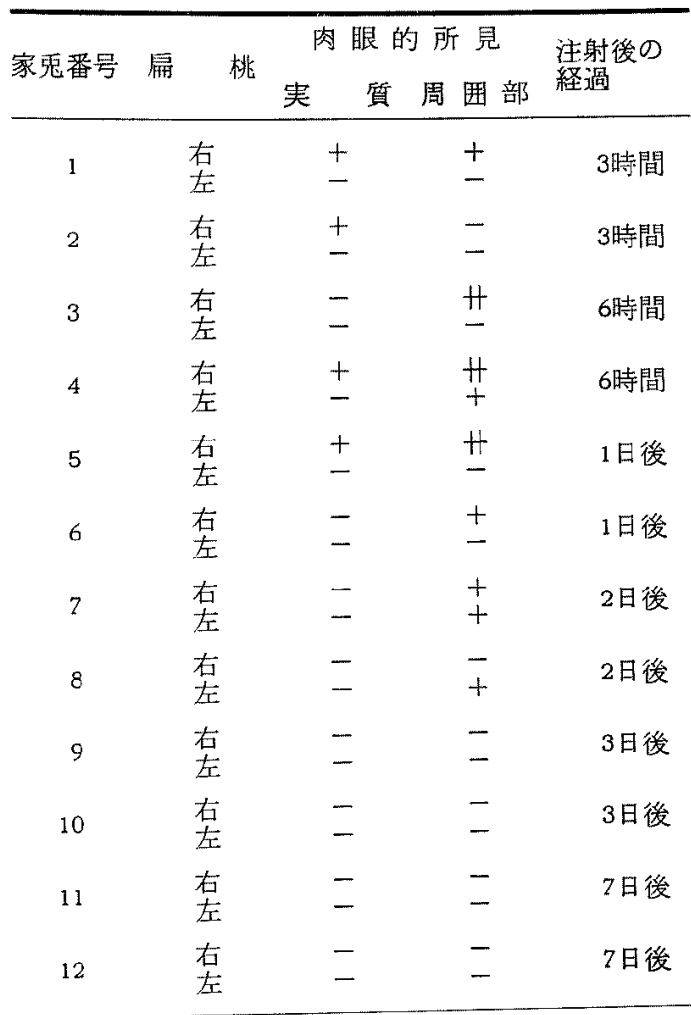

右: BSA 注射

左：生食水注射

た実質内間質の細胞浸潤は，好酸性細胞を主体として認 められ出血も散見される(図 4). 対照群, 反応惹起群 の病理組穖像についての所見は一括して表3に示した。

IV. 小括亡考按

実験的扁桃资の病理組織学的所見《ついての詳細な報 告は，従来より多くは行われていない，その中で，初期 に括いては扇桃炎の成因にせまるものとしての位置つけ

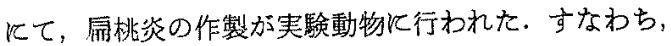
浜谷は上卜扁桃桨の成因の1つとして，アレルギーの関 与を予想し，扁桃のアレルギー资を家鬼作製した ${ }^{10)}$. その結果，関創りょウマチを有する扁桃の病理組織像に 酷似した実験的局桃炎の作製化成功した. 石尾は, 家兔 を用いて扁桃泣ェワルッマン型の炎症を作製した これの組織学的特微として, 㦿桃実質内の細胞浸潤, 出 血飞加えて，壊死，膿瘍等も認方られたと報告してい る.さらK, 井桃各部の血管に血栓形成が認められたと 


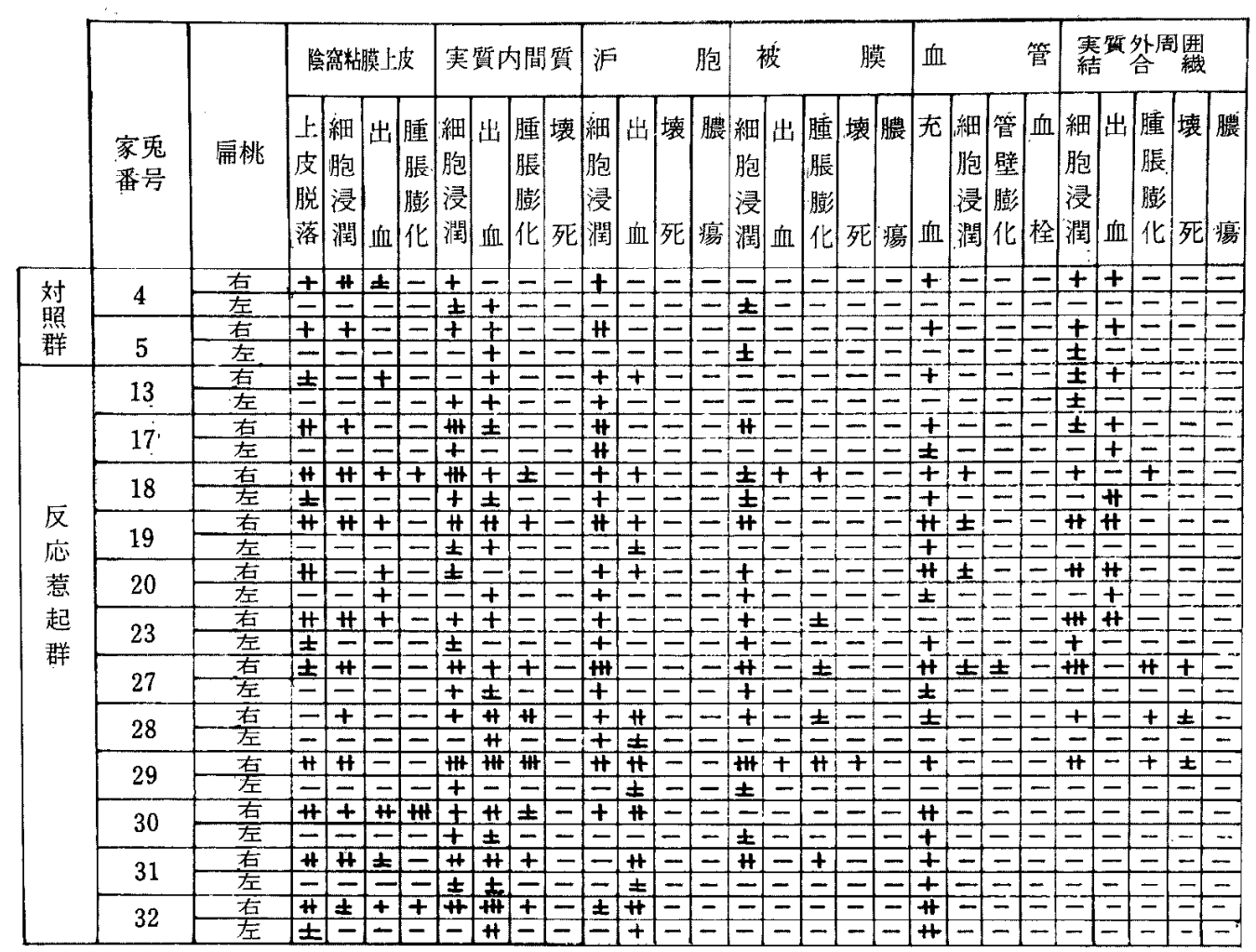

表 3 対照群，アルサ大反応惹起群の病理組織学的所見

右：BSA 注射左：生食水注射あるいは無処置

報告している，我々が作軽したアルサス型㴊桃资とシュ

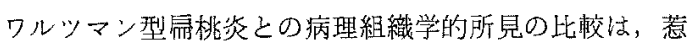
起物貿の搨桃組織への到達経路の進いという点で非常に 重要であると考えられる，そこで，以下にその此較を武

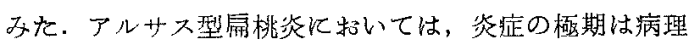
組織学的にみるならば，炭起注射後24封間から48時間に 出現した.これはシュワルッマン型聏挑炎のそれとほぼ 同様であった，し办し，組織像に括ける大きな遣いは， 前者では境死，膿湯，血栓の非成汃認められず，後者に 拈いてはこれらの形成が䛶められた点汇ある。一方，両 者に招ける惹起物質の違いにより, 組織像の差篻が生じ た可能性もあり，さらに吟味を武みた，すなわら，石狌 は細囷汇液，生菌括よび死菌浮遊液，卵珀アルブ:ンの 夫々を苾起物質として健用した。大腸葴泥液を使用した 場合，变化の鼠も強く現われた部位は，被膜执よび周国 結合織部であり，著明な充血，浮腄，出血さら飞高度の 細胞浸潤老認めている。艺うして，これらの变化は萀起 汒射後6 時間加ら24時間飞最す強く認めている。一方,
$2 \%$ 卯白アルブミン溶液をシュワルッマン因子として用 いた場合の変化としては，被膜括よび周絜組織の変化が

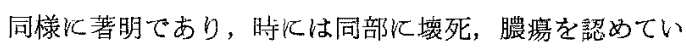
る.この結果加ら，生物学的洁性物質以外の異種蛋白を 䓗起物質として用いた場合でも，シュワルッマン型扁桃 炎では，垻死，膿簜を形成する。しかしながらアルサス

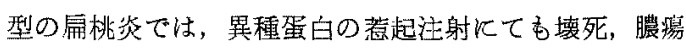
の北成までには至らなかった，奏験的屚桃炎の作製は，

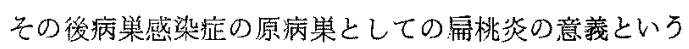
位固づけにて，各種の奏験的扇桃炎の研究が行われてい

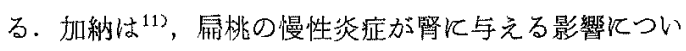
て検討を行っている．その中で扁桃の溶連菌感染が重要 であることを指適し，家隹遊挑炕A群溶連菌12型を注入

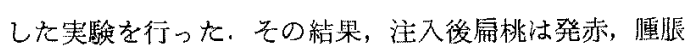
し腺䆚内に白荅を形成するものも諗められたと報告して いる.さらには，このよろな所見は $2 \sim 3$ 週間持続し，閶 桃組織内には小膿漡が形成されたと報告している。一 方, 兔疫担当臟器としての扁桃の值置づけのもとに実験 


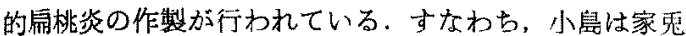

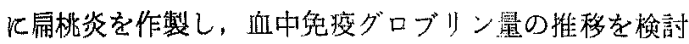
している ${ }^{12)}$ 溶連菌単独, および溶連菌と黄色ブドウ状 球菌の混合感染による薪桃炎を作製した，その結果，溶 連菌単独では局所の炎症所見は，1回目の注入では強く 出現するが，その後の注入では炎症所見が弱くなる。し たがって，黄色ブドウ状球菌との混合感染の間隔を調節

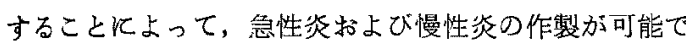
あると述べている。しかしながら，これら細菌感染によ る実験的扁桃炎の詳細な病理組織学的所見は述へられて いない，したがって，今回我々が作慜したアルサス型凩 桃资の病理組織像と, 細菌感染比よる組織像との比較検 討は行党なかった。一方，家鬼皮闌飞括けるアルサス型 炎症の病理組織学的検索は，林 ${ }^{1314}$ ，河野等 ${ }^{15}$ K上って 行われている. その結果, アルサス反應惹起後早期に血 管の透過性亢進，多型核白血球の浸潤を認めている. そ うして, 炎症の強い場合には壇死, 膿韵形成がみられた と報告している.

\section{第二節 アルサス型扁桃炎の血中線溶動態}

\section{I. 緒 言}

シュワルッマン型の炎症は，血管内凝固惿候群の病態 飞非常飞似た血液学的变化を呈することが知られてい $ろ^{18)}$ ．とく江 endotoxin を用いた全身性シュワルツマン 現象に括いては, 血小板, 線維菜原, プロトロンビン, 第V因子，第四因子の低下方認められている17)一方，

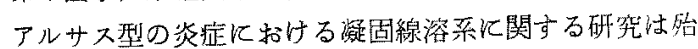
んど行われていない，ヒ卜扇桃炎モデルとしてシュワル ッマン現象を考える場合, 惹起物質の到達経路が全身性: （血行性）となる。このような夙桃炎の発症様式は，上 卜扁桃炎においては，敗血症に基づくものであり，非常 に稀であるといえる。したがつて，我冬はアルサス型の 殿桃炎を家鬼作製し，血湤中の protease，antiprotease の活性変動を線溶系沉ついて検討を行った，そうして， 反応暮起後経時的にこれらの活性を測定し，扇桃局所の 炎瘤所睍（肉眼的，組織学的所見）とこれらの变動の動 的相関について検討を行ったので報告する。

\section{II. 実跧方法}

○実験動物，感作方法，抗体価の測定方法は第一節にて 述へた方法に準じて行った，実験に用いた家兔柱部て

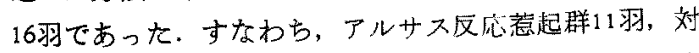
照群 5 羽で実験を開始した。実験に用いた家鬼㤝，抗体 洒方゙ $2^{4} \sim 2^{5}$ K上輩したすのを用いた，

\section{○蔆起注射の方法}

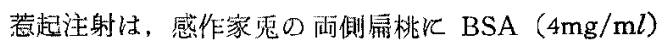
を $0.2-0.3 \mathrm{~m} l$ ずつ行った．対照群として感作家鬼の両 測雇桃に，生食水 $0.2-0.3 \mathrm{~m} l$ ずつ注射した。

\section{O採血方法}

$3.8 \%$ クンン酸ソーダ $1 / 10$ 容を人れた注射器にて、耳 静脈より採血した，採血後，直ちに $4^{\circ} \mathrm{C}$ 下，3000r.p.m.

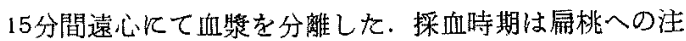
射前，BSA 注射後特上び生食水注射後であり，注射後 は経日的に搝血した。採血量の不足，あるいは赛験死の 動物もみられたため，測定数仿必ずしも各測定項目飞招 いて一致はしていない。

\section{○試 薬}

Fibrinogen: Armour 製 bovine fibrinogen (clottable protein $40 \%$ ) を用いた。

Urokinase：ミドリ十字製薬製 urokinase を用いた。

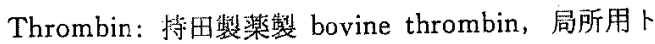
ロンビンモチダ 1000 unitsを用いた。

Streptokinase: Lederle 製 Varidase を用いた。

Lysine-sepharose：第一化学製を用いた。

\section{○测定方法}

Fibrinogen 戰の測定法

Quick 法の变法を用いた ${ }^{32}$.

Plasminogen 量の測定法

松本等 ${ }^{18)}$ の方法飞準じて, 佔漿を用いて lysinesepharose affinity chromatography 行った, 吸着部 分を $0.1 \mathrm{M}$ acetic acid にて溶出させ，これを plas-

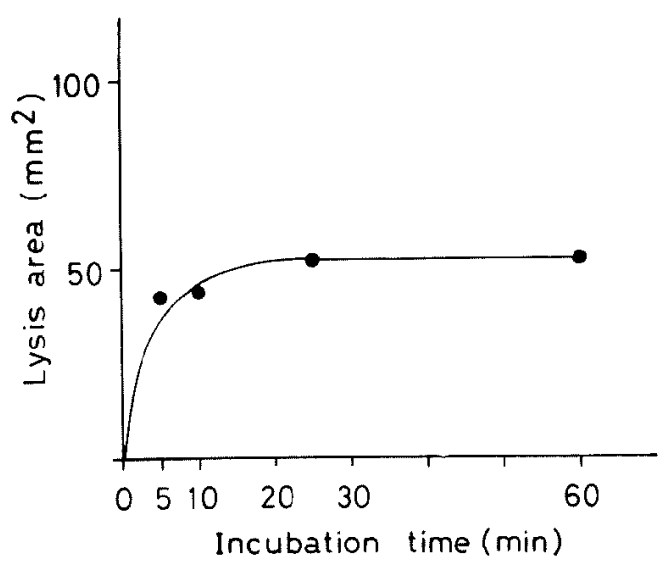

図 5 Plasminogen (Fraction II) の urokinase 比上る活性化 
minogen fraction として用いた. この分画を urokinase Kて活性化し， plasminogen free fibrin plate を用い て, その溶解面積より casein units K換算した ${ }^{193}$. urokinase による plasminogen の活性化の条件㹥urokinase $50 \mathrm{u} / \mathrm{m} l, 0.1 \mathrm{~m} l$ と plasminogen fraction $0.4 \mathrm{~m} l$ を混 じ，37 ${ }^{\circ} \mathrm{C} ， 25$ 分間の preincubation を行った（図 5).

Inhibitor 活性の測定法

lysine-sepharose affinity chromatography $K f_{3} \omega \tau$, 血漿の非吸着部分を inhibitor 分画とした，血然中に は，過剩の plasmin inhibitor が存在することが知られ て和り， urokinase とよる plasminogen activation 阻害することも知られている，そこで，血然の稀秎をど れ程行うことによって, urokinase とよる plasminogen activation の 50\%阻害が みられるが検討した. 正常

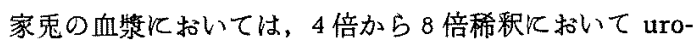
kinase 10 units $の$ plasminogen activation を、はぼ50 \%阻害することが解った（図 6).したがって，1ysinesepharose column K血椟 $1.5 \mathrm{~m} l$ をapply $し, 0.005 \mathrm{M}$ phosphate buffer $-0.85 \% \mathrm{NaCl}(\mathrm{pH} \mathrm{7.4)} 4.5 \mathrm{ml} \mathrm{k \tau}$ 非吸着部分を回收し，これを用いることによって，血禁

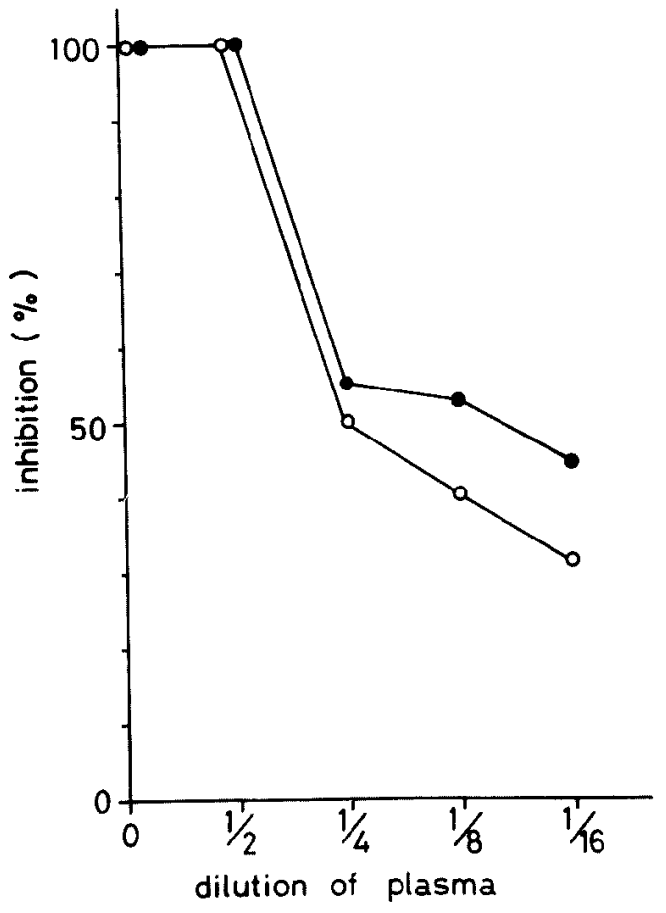

図 6 血漿の稀积之 inhibitor 活性 (無妈置家鬼 2 羽での測定結果)
中の inhibitor 活性を各家鬼において比較することが可 能である. したがって urokinase $(10 \mathrm{u} / \mathrm{m} l)$ K等量の inhibitor 分画を加光, $37^{\circ} \mathrm{C} 10$ 分間 preincubation 行い, plasminogen rich fibrin plate に滴下し，その溶 解䤄積を測定した。 inhibitor 活性は，对照として用い た urokinase 5 units の溶解面積炕対する抑制率として 計算した.

Euglobulin + Streptokinase（以下 Eug + SKと略す）值 の測定法

採血後 3 時間 以内に, 等電点沈激法を用いて euglo-

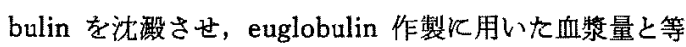
量の Borate-saline buffer ( $\mathrm{pH}$ 7.8) 飞溶解させたもの を euglobulin として用いた ${ }^{2021)}$ 。この euglobulin 分 画任 streptokinase 1000 units $/ \mathrm{m} l$ 等量加光, $37^{\circ} \mathrm{C}$ 15 分間の preincubation 後, plasminogen free fibrin plate に滴下し溶解面積を測定した.

III. 実瑍結果

OFibrinogen 量の推移（図 7)

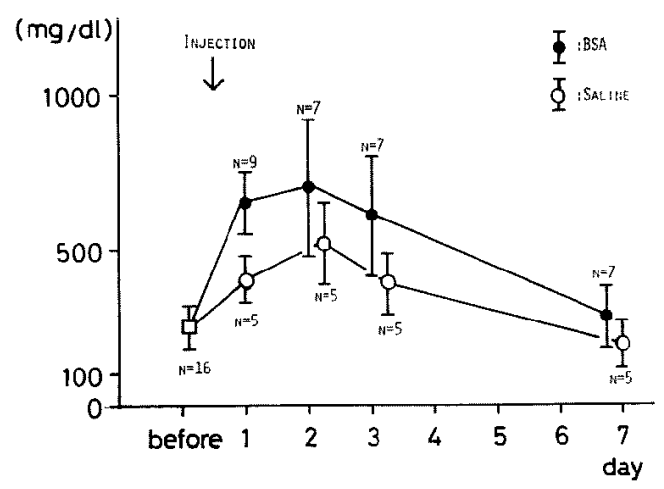

図 7 Fibrinogen 量の推移

$\Phi$ : meantstandard deviation

感作家鬼注射前の fibrinogen 量は, $250.3 \pm 71.4 \mathrm{mg} /$ $\mathrm{d} l$ (mean \pm S. D.) であった. 反応惹起群では, 惹起注 射施行後1 日炕て fibrinogen 量は $650.7 \pm 99.8 \mathrm{mg} / \mathrm{d} l$ (mean \pm S. D.) 飞增加し，3日頃より減少が認められ, 注射後 7 日にてほほ惹起注射前の fibrinogen 量飞民口 た. 一方, 対照群飞括いては, 注射後 1 日で fibrinogen 量加堌加し，7 日にて注射前値飞戻った，反応惹起群と 対照群との比較では，注射後1日，3日飞前者に和いて t-test で有意憎加していた $(P<0.001, P<0.025)$. 


\section{OPlasminogen 量の推移（図 8)}

注射前の plasminogen 量は $5.2 \pm 2.2$ casein units/ $\mathrm{m} l$ (mean士S. D.) であった. 反応䓺起群では, 萀起注 射施行後 1 日，2 日，3日にて注射前に比して減少傾向 が認められた. しかし，注射後7日にては注射前の plasminogen 量飞戻った. 一方, 対照群では, 注射後 1 日，2 日にて実験動物間でのバラッキが多く認められた が, 注射前值に比して変動はあまり多く認められなかっ た. 注射後 7 日では, 注射前值よりもやや低下傾向を示 した，反応㴔起群と対照群との比較では，注射後全経過 を通じて, plasminogen 量の差を統計学的に有意には認 められなかった。

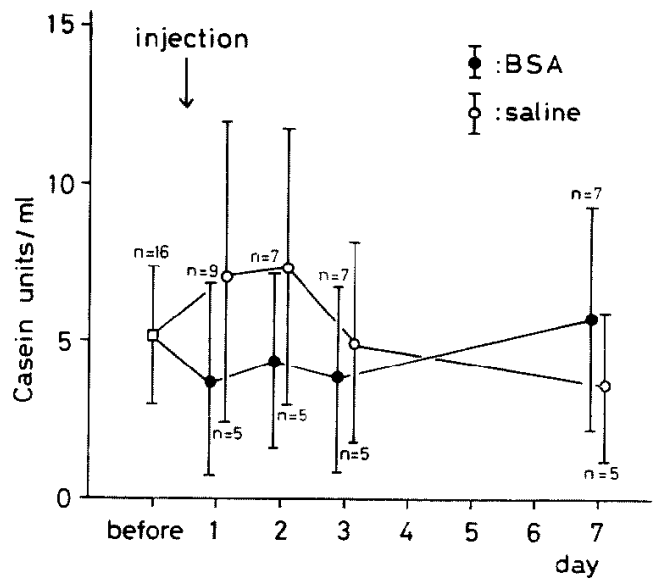

図 8 Plasminogen 量の推移

王 : mean+standara deviation

OInhibitor 活性の推移（図 9)

注射前 $\Phi$ inhibitor 活性は, urokinase 10 units $飞$

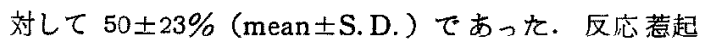
群では，注射後1日，2日，3日でほほ 100\%の抑制活 性が諗められた。また, 惹起注射後 7 日で注射前值に戻 った.一方，対照群に执いては，注射後1日，2日でほ ほ 100\%の抑制活制が認められた。そろして3日後では 抑制活性が減少しはしか，7 日後では注射前值に戻った。 反応惹起群と対照群との比較では，注射後 3 日にて前者 において, 統計学的に有意に inhibitor 活性が増加して Wた $(P<0.05)$.

OEug +SK 值の推移（図 10）

注射前の Eug $+\mathrm{SK}$ 值は $50.18 \pm 34.9 \mathrm{~mm}^{2}$ (mean士 S.D.) であった。 反薏起では注射後 1 日にて, Eug十

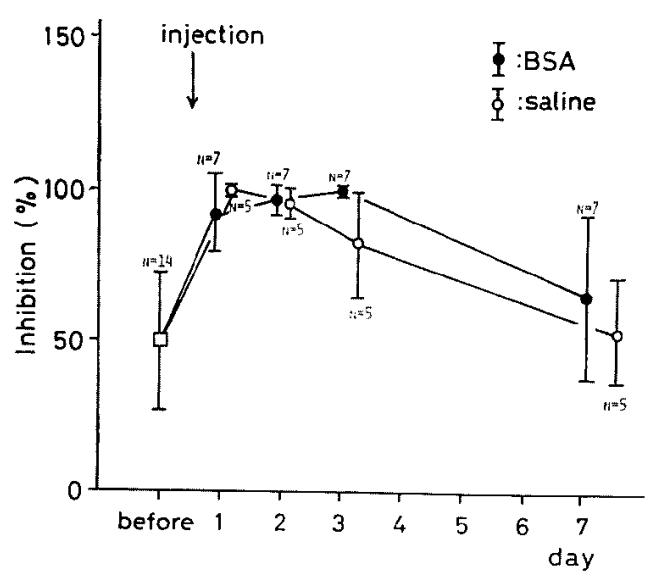

図 9 Inhibitor 活性の推移

玉 : meantstandard deviation

SK 岋 plasminogen rich fibrin plate Kて殆んど溶解 を示さなかった. その後徐々飞活性が出現し，惹起注射 後 7 日にて注射前值に戻った. 一方, 対照群飞打いては, 注射後 1 日，2日では注射前值上大幅な変化が認められ ず，3日後には注射前值に戻った。 反芯薏起群と対照群 との比較では, 注射後 1 日にて前者に扎いて, t-test て有意に Eug +SK 值方減少していた $(\mathrm{P}<0.025)$.

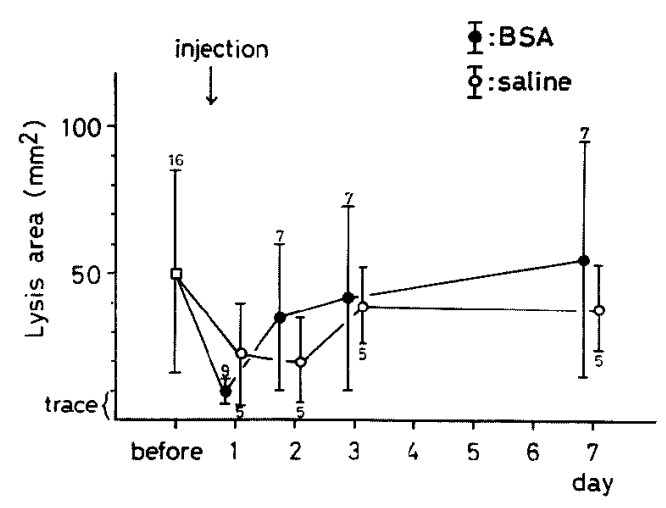

図 10 Eug + SK (whole plasmin) 值の推移 玉 : meantstandard deviation

\section{IV. 小括亡考按}

acute phase reactant としての fibrinogen 量の推移は, アルサス型開桃炎薏起後 1 日，3日で対照群に比して統 計学的に有意譜加していた.しかし反応薏起群, 対照群 とまに7日後には注射前值に扊っていた.この fibrinogen 
量の推移を、シットの化学炎症にみられた推移と比較し てみると，ほほ同様の推移を示したが229，炎症聕起後 24 洔間での fibrinogen 壆の增加は, 家兔におけるアルサ

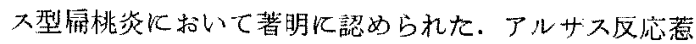
起群および刘照群において, 線溶活性の各 parameter

\begin{tabular}{|c|c|c|c|c|}
\hline aere & Fibrinogen & Plasminogen & Inhibitor & Eug : SK \\
\hline$B S A$ & $\boldsymbol{t} \uparrow$ & $\downarrow$ & $\uparrow \uparrow$ & $\downarrow \downarrow$ \\
\hline Saline & $\uparrow$ & $\rightarrow$ & $\uparrow \uparrow$ & $\Rightarrow$ \\
\hline
\end{tabular}

表 4 注射後24待間の各 parameter の变動

の注射後24時間の変動を，注射前のそれと比較し表 4 K まとめた，すなわち，両群の比較を行うと fibrinogen 量 の增加, plasminogen 量の減少傾问, Eug $+\mathrm{SK}$ 值の低 下が反応蕊起群化打いて認为られた。しかしながら， urokináse 用いての inhibitor 活性の测定飞执いて は, 反応惹起群, 対照群ともに同じ程度の抑制活性が出 現した.これらの parameter の測定結果より，アルサ 入型扁桃炎の発症初期汇招いては線溶活性の亢進が生じ たものと考えられた.すなわち，plasminogen 量の減少 傾向は plasmin 八の活性化炕より生したたためであり， Eug +SK 值の低下は活性化された plasmin が炎症局所 に颃いて consumptionされれたのと推諭した。

\section{総括亡考按}

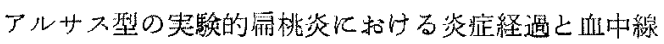
溶活性の推移々の関連を，線溶系因子の变動を追求する ことによって明らかにした。すなわち, 惹起注射施行後 1 日, 2 日飞扁桃局所で恃，細胞浸潤，あるい恃出血が 最も強く認められた。一方，この時期汇一致して血中 plasminogen 量の減少傾向, plasmin の consumption が生じている事実が呈示された，それでは，この血中線 溶醅素が，アルサ大型虔桃炎の病理組織像の形成にどの ような意義をもっているのか，以下に文献的考察を試み た. plasmin 蛙，关れ自身で血管透過性九進作用を有し ていることが知られている233 この事実から，徧桃の浮 軍，血管允血化重要な関与をしているものと思われる。 また，楾溶活性の異常艺進は，摃賃血管の目然止血機構 に娰して障害的任作用すると考えられている。すなわ ち，損甥血管，破綻した血管は，血小板の粘着，凝集を 経て血栓形成が行われる。その後この血栓の過剩な部分 が，生理的に plasmin Kよって除去され血流の正常化
が行われる、しかし，血中の線溶活性，あるいは破綻血 管周团組織の plasmin 活性が 上暈している場合には, 止血のための血栓形成加㧕制されたり，一旦形成された 血栓が強い溶解を示し，出血がな扔も持続する結果とな

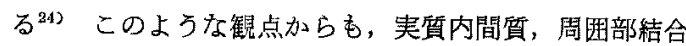
織の出血と血中線溶活性の元進は重要な関わりを有して いると考えられる，一方，アルサス型扁桃炎での細胞浸 潤は，扇桃の各部で認められている。この緗胞浸潤は多 型核白血球，好酸性細胞が主体をなすものであり，惹起 注射施行後24時間加 48 時間に著明飞認められた。これ らの白血球浸潤を生ぜしめる物質は，扁桃局所飞招いて いかなるあのであるか、今後更に追求されなければなら ない。

\section{結論}

1）上卜急性绵桃炎のモデルとして，家兔に了ルサス型 病桃炎を作製し，肉眼的，病理組織学的観察を行いその 有用性が明らかとなった。

2）肉眼的観察では，惹起注射施行 1 日から 2 日後に， 浮腫, 出血性変化を認めた。 しかし, 生食水注射沜桃に おいては僅かな浮腫を認めるのみであった。

3）病理組織学的検索では，惹起注射施行 1 日後に执い て最手強く茨症反応が認められたすすなわち，履桃実質 部, 周困部の細胞浸潤, 出血が誌められた。

4）血中線溶活性の変動では，注射施行1日後に括いて， 反心若起群は対照群飞比して fibrinogen 量の増加, plasminogen 量の減少傾问, Eug +SK 值の減少を認め た。しかし，inhibitor 活性は両群飞招いて同じ程度に 增強していた。

5）これらの結果より、アルサス型家象闌桃炎において， 惹起注射後24時間加 548 時間にて血中線溶活性の亢進加 認められ，この線溶活性六進が炎店反応の経過江重要な 意義をもつあのと推論した。

\section{文献}

1）小杉忠誠，松山秀明，非浦昭克，浜谷松夫：急性柠

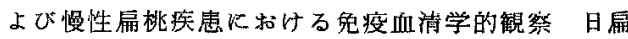
桃誌 $610: 123-126,1971$,

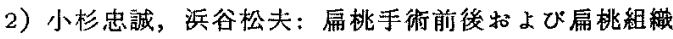
抽出液の線溶動態飞ついて 耳鬼 21：162-169， 1925.

3）小杉忠誠，浜谷松夫: Protease-antiprotease の観点 上り 及大扁桃炎の破究 第 1 報 ヒ上急性扁桃炎の血

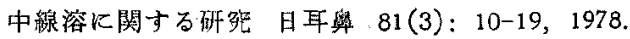


小杉論文 付困 (1)

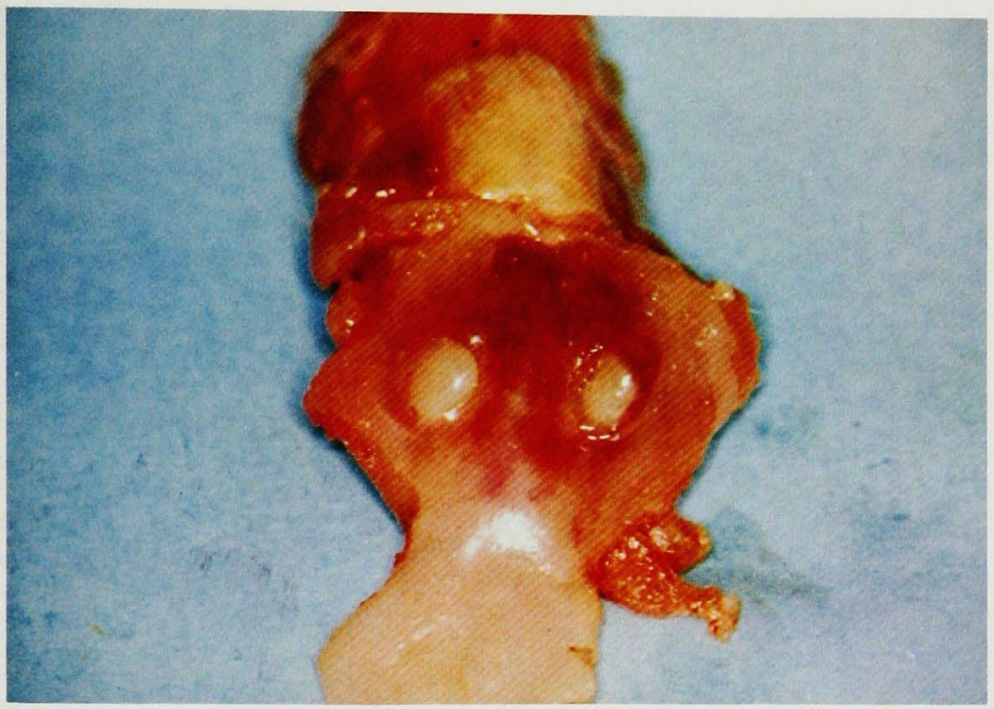

図 2 家鬼番号18の扁桃（肉眼的所見）

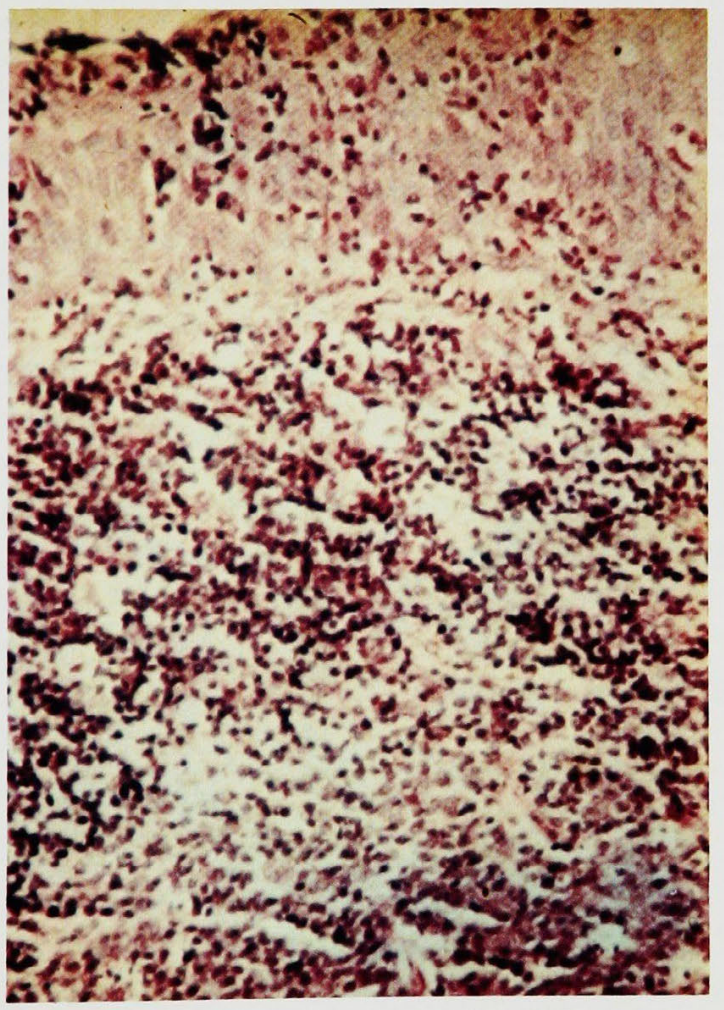

図 3 家鬼番号18の扁桃組織学的所見 (㓌窩粘膜上皮部) 


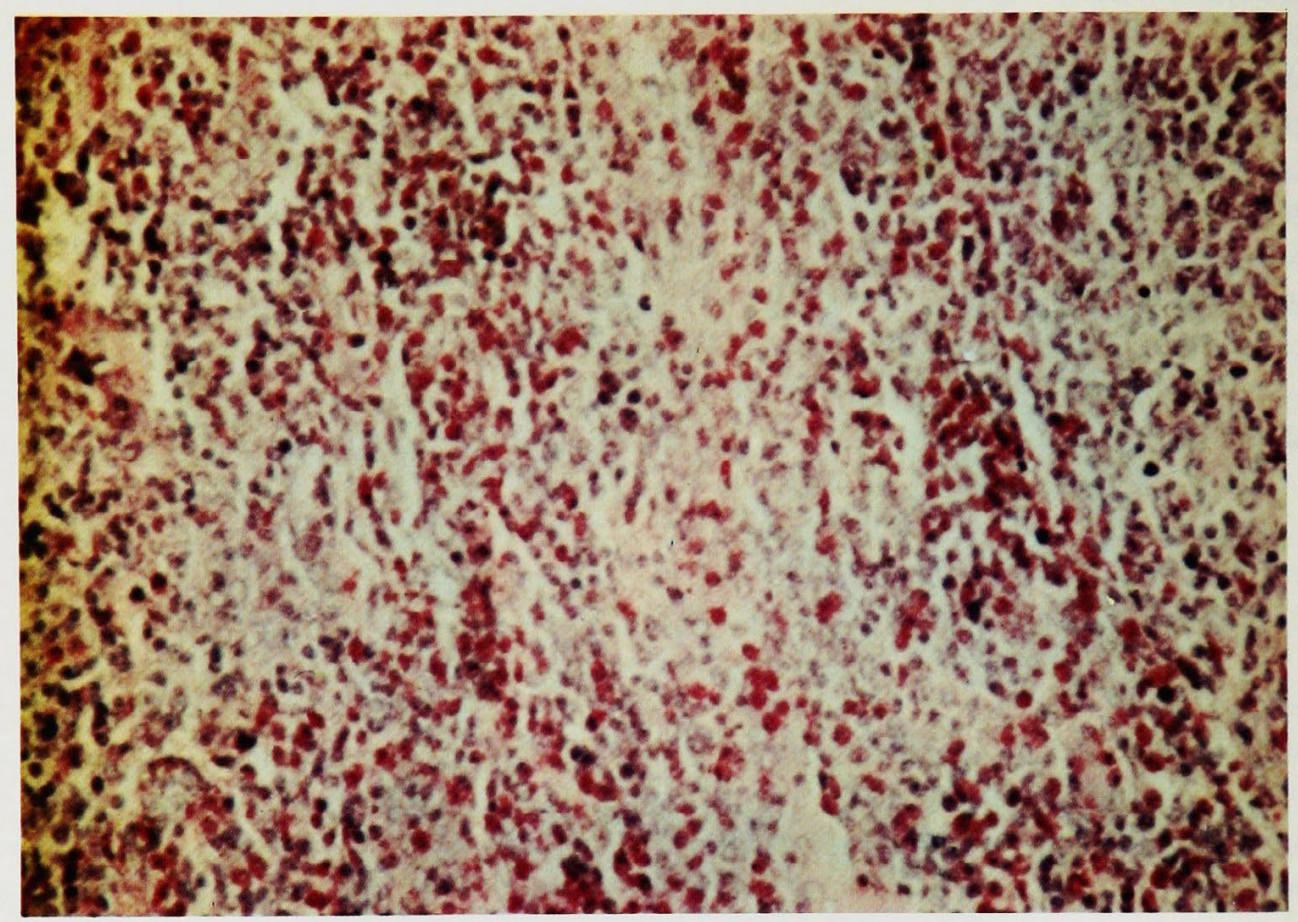

図4家鬼番号18の右扁桃組織学的所見 （実質内間質） 
4) Kosugi, T. et al.: Fibrinolytic activity in tonsillar tissue of man. J. Saitama Med. School, 4: 175-180, 1977.

5）細川 継：日蓋扁挑中の Plasmin activator 特上び inhibitor について 日扁挑誌 7: 101-114, 1967.

6）小杉忠誠，浜谷松夫: Protease-antiprotease の锶点 上りみた扁桃炎の研究第2 報七卜扁桃組織の線 溶系関与物質记関する研究 日耳鼻 81(4)：35-43， 1978.

7) 木村一郎：抗原抗体反店（in vitro の測定法），重 層法 兔疫学フレルギー学実娩法 246-256, 文光 堂, 東京, 1971 .

8) 石尾和敏：扁桃におけるシュワルッマン型組織反応 の実駼的研卶 北海道医学雑誌 $33(7,8): 65-89$ ， 1958.

9）影山圭三，福田純也，山口寿夫：アレルギー性組䄉 反応, 免疫学アレルキ゚ー学実彁法 461-491, 文光 堂, 東京, 1971 .

10）浜谷松夫：扁挑の実験的アレルギー 北海道女子医 專紀要 1: 40-41，1949.

11）加納祜雄：扁桃の慢性炎症が堅に及活す影響につい 乙 日耳嶴 78(4)：10-17，1975.

12）小島健二：扁桃摘出炕上る免疫グロブリンの変脸に 関する研究 日耳鼻 78(5)：56-70, 1975.

13）林秀男, 河野正, 山本俊輔, 告永秀: 炎轻上

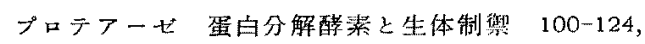
東大出版会, 東京, 1973.

14）林 秀男: 炎症の発生と抑制一形態学々生化学老む すぶための試み一日本医事新報 $72 ： 3-5 ， 1967$.

15) 河野 正, 武藤 真, 林 秀男: 炎症に和けるプロ テアーゼの役割 臨床科学 4(10)：1252-1262, 1968.

16）岡本彰祐：内科疾患飞机ける線溶系の意義, 序説 綜合監床 24(11)：2665-2667，1975.
17）具木正博：血管们血液凝固症候非金原出版，京都， 1970 .

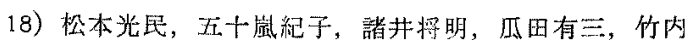
節夫, 浅田敏雄: 吸着クロマトによる血中ブラスミ ン扣よびプラスミノーゲンの泪定法 東邦医学雑誌 $20: 83-87,1973$.

19）小杉忠誠：副舅腔炎手術に対する抗ブラスミン剤投 与.の䐿討 耳輿 22(3):442-462，1976.

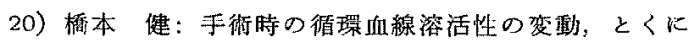
湘定法の吟味と活性変動の意義について，䟽床血液 10(5): 610-619, 1969.

21）站本歌子, 大柴 進: ユーダロブリン溶解時間測定 法線溶現象の基礎と臨床 395-398, 医学書院, 東京, 1966 .

22）小杉忠誠，松尾 理，美原 恒：化学炎症に括ける 凝固線溶能の研觉 プラスミン研究会報告篹 16 : $186-189,1976$.

23）逢坂 昭：血管透過性の生化学一赤血球の漏出機栦 を中心に一生化学 48(6): 308-331，1976.

24）美原恒：出血に括忛る楾溶の意義血液と脈管 $1(1): 19-28,1970$.

稿を䅂えるにあたり御指尊頂きました宮崎医科大学生 理学教室松尾理助教授, 美原恒教授, 埼玉医科大学耳器 咽喉科浜谷松夫教授に染甚なる謝意表すると共に，御 示唆々御援助を頂いた神戸大学医学部生理学教室岡本彰 祐教授に整心より感謝致します。本諭文の要旨は，第79 回 日耳率総会，第127回日耳楀北海道地方会にて発表 L た.

(原稿受付 昭和53，5，31日）

別刷請求先 $\bar{T} 889$-16 宮崎紧宮崎郡清试町木原 宮崎医科大学生理学第 II 講座 小杉忠誠 